\title{
Intersectional Perspective of Strengthening Climate Change Adaptation of Agrarian Women in Cameroon
}

\author{
Faith Ngum and Johan Bastiaensen
}

\section{Contents}

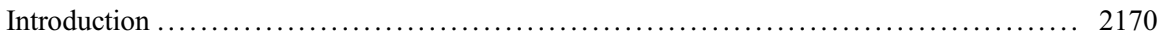

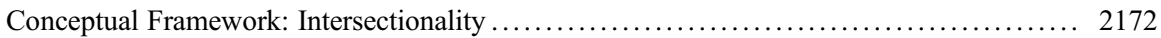

Climate Change Vulnerability and Effects Across the Different Agro-ecological Zones .... 2173

The Sudano-Sahelian Zone ........................................... 2173

The Guinean Savannah Zone .......................................... 2175

The Western Highlands Zone ......................................... 2175

Coastal Lowlands or Mono-modal Forest Zone ................................ 2175

The Bimodal Forest Zone ............................................ 2176

Farmers Household and Community Adaptation Strategies ....................... 2176

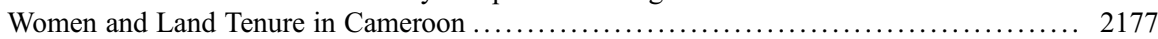

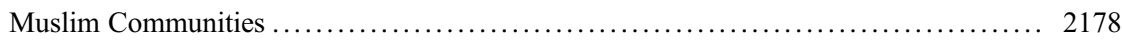

Anglophone Communities .............................................. 2179

Francophone Communities .............................................. 2180

Intersectionality and Climate Change Adaptation ............................. 2181

Women and Climate Change Adaptation Within the Muslim Community ............ 2181

Women and Climate Change Adaptation Within the Anglophone Community ......... 2183

Women and Climate Change Adaptation Within the Francophone Community ........ 2185

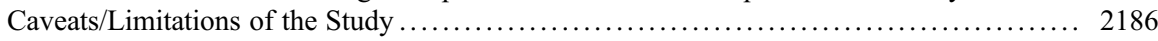

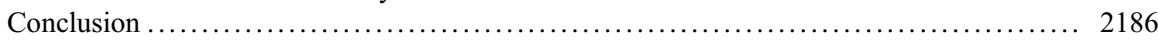

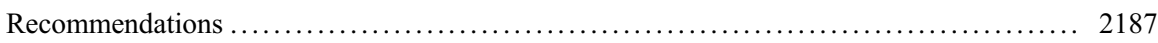

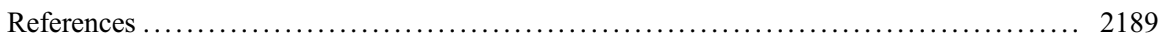

This chapter was previously published non-open access with exclusive rights reserved by the Publisher. It has been changed retrospectively to open access under a CC BY 4.0 license and the copyright holder is "The Author(s)". For further details, please see the license information at the end of the chapter.

\author{
F. Ngum (ه) \\ Lilongwe, Malawi \\ J. Bastiaensen \\ Institute of Development Policy (IOB), University of Antwerp, Antwerp, Belgium \\ e-mail: johan.bastiaensen@uantwerpen.be
}




\section{Abstract}

It is a widely accepted notion that climate change affects men and women within agrarian populations differently; consequently, their adaptation strategies are gendered. Besides climate change, women's vulnerability and their corresponding adaptation strategies are embedded within a complex web of social identities/status, agroecological location, gender norm/roles and power struggles within the plurality of normative orders governing land (property rights). This chapter focuses on Cameroon and seeks to analyze how the interactions between various normative orders governing access to land, co-dependent upon the multiple gendered identities (intersectionality), impact climate change adaptation strategies of female farmers. The results show that the degree of vulnerability and adaptation strategies of women are context specific and gendered across the five distinct agroecological zones of Cameroon. Furthermore, secured access to and ownership over land is crucial in determining the adaptation choices and options available to female farmers. A complex mix of state and non-state norms govern property rights in Cameroon, within which women have to constantly negotiate their land claims. These negotiations are influenced by marital status, ethnicity, educational level, and community/social relations, such that the outcome translates differently for women within the Muslim, Anglophone, and Francophone communities. The chapter concludes with context-specific recommendations to strengthen the adaptive capacity of agrarian women across Cameroon.

\section{Keywords}

Women $\cdot$ Property rights $\cdot$ Intersectionality $\cdot$ Climate change $\cdot$ Adaptation Cameroon

\section{Introduction}

Climate change and its adverse effects on the livelihoods of agrarian communities in the global south have gained visibility within global development debates. Although these adverse effects are diverse and context specific, they are projected to hit developing countries in the global south the hardest due to technological, resource, and institutional constraints to adaptation, as well as their over dependence on natural resources as a livelihood base (Ngondjeb 2013; Pumenta 2014). Furthermore, issues of gender and climate change adaptation are increasingly being raised as women are looked upon as a marginalized vulnerable group relying on agriculture and natural resource related activities for sustenance (Denton 2002; Arora-Jonsson 2011; Kaijser and Kronsell 2013). Gender roles/norms, unequal power relations, differential access and entitlements to land entails differences in the level of vulnerability, and effects of climate change on agrarian men and women, as well as their adaptive capacity. Thus, it is a widely accepted notion that climate change affects men and women within agrarian populations differently; 
consequently, their adaptation strategies are gendered (Denton 2002; Arora-Jonsson 2011). However, most studies focus on the binary construction of gender (men vs. women) thereby overlooking the influence of other factors such as geographical location, social relations, power, social/societal norms, social identities, etc. on the adaptive strategies of farmers, especially women (Kaijser and Kronsell 2013; Osborne 2013; Carr and Thompson 2014; Kings 2017). Recent intersectionality approaches to gender analysis have, however, demonstrated that the gender binary needs to be interconnected with other markers of identity and social position (Kaijser and Kronsell 2013; Osborne 2013; Van Aelst and Holvoet 2016; Boltana 2017; Elum et al. 2017).

In an agrarian economy like Cameroon with five distinct agro-ecological zones where subsistence agriculture is the mainstay for about $80 \%$ of the country's population (Molua 2011; Pumenta 2014), the effects of climate change are multiple and diverse, with negative consequences dominating. With most smallholder farmers highly dependent on rain-fed agriculture, climate variability and changes are detrimental to their livelihood base and as such the agricultural sector is among the most vulnerable to the risks and impacts of climate change (Tingem and Rivington 2009; Pumenta 2014). Although agriculture is the livelihood base for most Cameroonians, women are the backbone of smallholder agriculture and food crop production, bearing most of the responsibility of household sustenance. Women constitute $51 \%$ of the entire Cameroonian population, $51.3 \%$ of whom rely exclusively on livelihood activities that are directly linked to the natural environment (Molua 2011; UICN-PC 2015; Beckline et al. 2017). Women are thus highly vulnerable to the impacts of climate change. Besides climate change, the agrarian livelihood base of these women is further complicated by a dual land tenure system within which women (based on their social identity/status and related gender norms) are constantly negotiating land access and rights, trying to mobilize the appropriate gender and customary norms that can be used to enforce their land claims (Faith 2019). Thus, women's vulnerability to climate change and their corresponding adaptation strategies are embedded within a complex web of social identities, gender roles, and power struggles over land within the various agroecological zones. Hence, the need to look at an intersectional perspective of factors that influence climate change adaptation strategies of agrarian women in Cameroon.

This chapter therefore seeks to analyze how the interactions between various normative orders governing access to land, co-dependent upon the multiple gendered identities (intersectionality), impact climate change adaptation strategies of female farmers in Cameroon. It reviews how climate change affects agrarian populations and how they generally adapt, both at the household and community level. Specific attention will then be given to women's access to farmland within the plurality of normative orders governing land and how land rights, social identities, and socioeconomic factors jointly influence their adaptation strategies (intersectionality).

This chapter is an exploratory desk study based on general literature review and discourse analysis of peer-reviewed journal articles, government policy documents, reports, and other unpublished texts about gender/women, climate change 
vulnerability and adaption strategies, intersectionality, and land governance. A keyword search was used to identify and isolate relevant texts, using gender/ women, climate change adaptation, climate change vulnerability, intersectionality, smallholder farmers, and land tenure as keywords. Approximately 50 documents were obtained from the keyword search. In order to understand the current/recent dynamics relating women and intersectionality to land tenure, climate change vulnerability and adaptation in Cameroon, the focus was on literature (journal articles, policy documents, reports, etc.) produced within the last 10 years (20092019), except one document on land tenure issues in Cameroon which dates back to 1996. This document was retained because no other recent/current document was found. Thus, based on their relevance to the study, a quick scan through the 50 documents obtained led to the elimination of 15 documents. In summary, this chapter exploits literature from 35 documents on the following thematic areas:

- Gender, climate change vulnerability and adaptation strategies

- Land rights, smallholder agriculture, intersectionality, and climate change adaptation

\section{Conceptual Framework: Intersectionality}

This study adopts the concept of intersectionality that emerged as a critique of the universalism of women's oppression portrayed by initial Western feminist movements. The concept of intersectionality was first used by black feminist (specifically by Kimberlé Crenshaw) to elucidate the triple oppression and discrimination of women of color resulting from an interplay of race, gender, and class. Although the concept emanates from black feminist movements, it has evolved over the years into multiple disciplines of feminist research to illuminate the interconnectedness of power and multiple axes of irreducible social categories (beyond race, gender, and class), and their effect on the identity and lived experiences of women (Davis 2008; Cho et al. 2013; Kaijser and Kronsell 2013; Kings 2017). However, even within feminist research, intersectionality has been defined, interpreted, and used in various ways (an analytical tool, a research paradigm, a buzzword, etc.). Given the ambiguity and open-endedness of the concept, we define intersectionality as "the interaction between gender, race and other categories of difference in individual lives, social practices, institutional arrangements, and cultural ideologies and the outcomes of these interactions in terms of power" (Davis 2008, p. 68). This definition highlights the fact that intersectionality is inextricably linked to power analysis between an infinite combination of overlapping social identities and categories that culminates to inequalities, discrimination, and oppression within a broader societal context. Put simply, intersectionality acknowledges that oppression is the outcome of interactions of multiple simultaneously linked identities, power relations, and lived experiences. Thus, the concept of intersectionality has been applied in myriad ways within critical feminist studies to highlight the historical "situatedness," social relations, and power structures that results into the irreducible, layered and co-constitutive identities of women within in a given context (Cho et al. 2013; Osborne 2013; Hankivsky 2014). 
Within the context of climate change, "[t]he responsibility, vulnerability, and decision-making power of individuals and groups in relation to climate change can be attributed to social structures based on characteristics such as gender, socio-economic status, ethnicity, nationality, [...] and place" (Kaijser and Kronsell 2013, p. 420). Consequently, the impacts and corresponding adaptations strategies of individuals and groups may reinforce or alternatively change these social structures and categories. Thus, the degree of climate change vulnerability, impacts, and adaptation strategies of smallholder farmers (especially women) is influenced by multiple intersecting social identities embedded in power structures (Arora-Jonsson 2011; Kaijser and Kronsell 2013; Osborne 2013; Carr and Thompson 2014; Hankivsky 2014; Kings 2017). Hence adopting the lens of intersectionality moves beyond "women as a homogenous analytical category" to unravel the dynamics of the interconnectedness of power, social relations, socioeconomic status and their various co-constitutive and mutually enforcing identities of women in relation to climate change vulnerability, impacts, and adaptations. This permits an informed and constructive understanding of gender and the multiple normative orders that determine the lived experiences and "true" effects of climate change on women within agrarian communities in Cameroon. An intersectional approach will therefore incorporate the concepts of gender, land tenure, and socio-economic status so as to gain critical and constructive insights on the vulnerability, impacts, and adaptation strategies of over $50 \%$ of women in Cameroon reliant on agriculture and other natural resource base activities for sustenance in different agroecological zones.

\section{Climate Change Vulnerability and Effects Across the Different Agro-ecological Zones}

In an agrarian economy like Cameroon, where a majority of the population rely on rain-fed agriculture and natural resource exploitation (especially forestry and nontimber forest products-NTFPs) for sustenance, climate change impinges on the climate-sensitive livelihood activities of most Cameroonians. Cameroon currently faces increased annual average temperatures and seasonal rainfall fluctuations with accompanying hazards such droughts, floods, heat waves, mudslides, etc. which are experienced differently across the country's agro-ecological zones, with diverse effects and impacts on the farmers. Located between West and Central Africa, Cameroon has five distinct agro-ecological zones with distinct topographic and climatic diversity which can be assumed to account for the variations in the degree of vulnerability and corresponding effects on agricultural activities within each zone (Yengoh et al. 2010; Pumenta 2014; MINEPDED 2015). Figure 1 presents five agroecological zones and their distribution across the national territory.

\section{The Sudano-Sahelian Zone}

Covering the North and Far North Regions, it is the driest part of the country with a semiarid climate. Annual temperatures here range between $17{ }^{\circ} \mathrm{C}$ and $34{ }^{\circ} \mathrm{C}$ over 


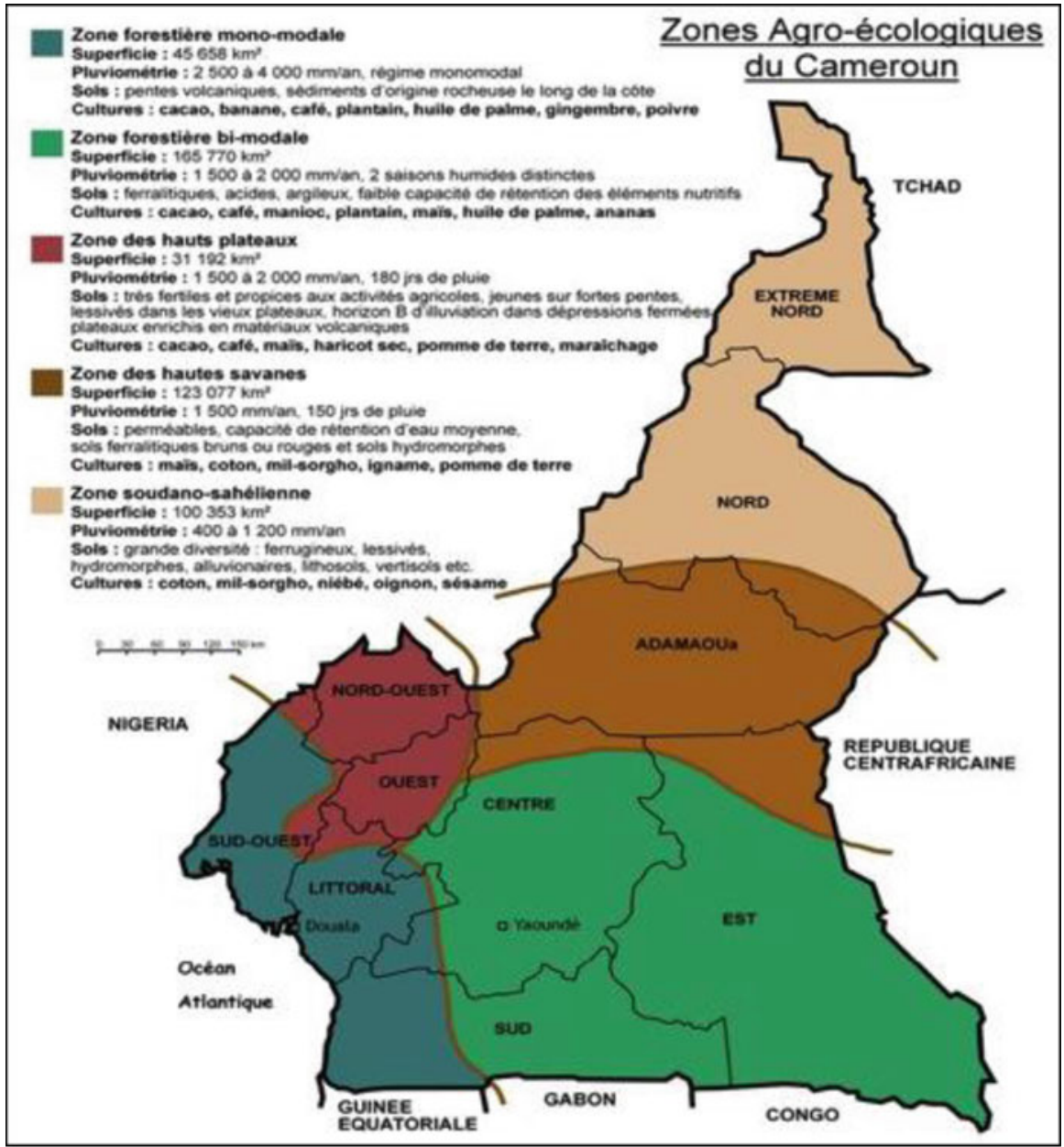

Fig. 1 Agro-ecological zones of Cameroon. (Source: MINEPDED 2015, p. 24)

long periods of the year making it highly vulnerable to droughts, heat waves, and dry spells. Despite its low rainfall distribution (between $400 \mathrm{~mm}$ and $1200 \mathrm{~mm}$ ), extreme interannual variability often with strong torrential showers are common, making the regions periodically vulnerable to floods (with high incidence of waterborne diseases). It is the most vulnerable zone in Cameroon with serious repercussions on the agricultural sector. Some of the consequences of climatic variations include: drop in crop yields (resulting from poor germination, crop drying), decreased fodder coverage, increased proliferation of animal pest (especially tsetse fly) and livestock mortality, drying up of water bodies (lakes and ponds), drop in fish production, and exhaustion of fish stocks. The abovementioned consequences translate to famine and food insecurity, increased conflicts over arable land, and population migration to other regions (Yengoh et al. 2010; Pumenta 2014; MINEPDED 2015). 


\section{The Guinean Savannah Zone}

It covers the Adamawa region and is a transition zone between the moist equatorial southern regions and the drier Sahelian northern regions. It is characterized by average temperatures of $22{ }^{\circ} \mathrm{C}$ and annual rainfall ranging between $700 \mathrm{~mm}$ and $1500 \mathrm{~mm}$ making it suitable for production of a variety of crops and livestock. This zone is considered the "breadbasket" of the country but with increasing temperatures, decreasing precipitation together with erratic rainfall patterns, the region is vulnerable to droughts, dry spells, and heat waves. The effects and impacts of climate variations in this zone are similar to those of the Sudano-Sahelian zone presented in the previous section, although more moderate (Yengoh et al. 2010; Pumenta 2014; MINEPDED 2015).

\section{The Western Highlands Zone}

It covers the West and North-West Regions of the country. Although it has a savannah vegetation, its mountainous topography with high plateaus (over $800 \mathrm{~m}$ tall) influences its climate. Influenced by this orographic effect, its annual rainfall ranges between $1500 \mathrm{~mm}$ and $2000 \mathrm{~mm}$ with an average temperature of $20^{\circ} \mathrm{C}$ giving it a cold equatorial climate with the possibility of off-season rains. This region experiences the highest seasonal fluctuations of rainfall and temperature patterns. Climate variations here results in drop in crop yields (crop decay during flooding, soil leaching, and erosion), increase proliferation of animal pest (especially tsetse fly), and livestock mortality. These translate to increased competition over arable land and farmer-grazer conflicts. However, erratic rainfall patterns provide the opportunity of off-season farming and thus stabilizing crop production in this zone (Molua 2009; Yengoh et al. 2010; MINEPDED 2015; Innocent et al. 2016).

\section{Coastal Lowlands or Mono-modal Forest Zone}

It covers the Littoral and South-West mountainous regions characterized by a rainy, hot, and humid equatorial climate. It registers the highest rainfall in the country ranging between $2500 \mathrm{~mm}$ and $4000 \mathrm{~mm}$ throughout the year with mean temperatures of $28{ }^{\circ} \mathrm{C}$. The population practice artisanal fishing and fish farming, and its rich volcanic soils, moisture-laden tropical maritime climate, and sea access makes it suitable for roots, tubers, and plantation agriculture. However, with increasing temperatures and intense rainfall, this zone is vulnerable to sea level rise, storm surges, floods, and mass movements such as landslides, mudslides, and falling rocks with negative effects on the population. Variations in climatic parameters results in increased proliferation of pest (malaria parasites), saline water intrusion and destruction of salt-intolerant crops, destruction of mangrove habitats, and increased waterborne diseases. However, increased sea temperatures also lead to improved fish habitat and changes in fish species diversity, hence a beneficial effect of climate 
change (Yengoh et al. 2010; Bele et al. 2013; MINEPDED 2015; Beckline et al. 2017).

\section{The Bimodal Forest Zone}

Covering the Center, South, and East Regions of the country, this zone harbors the country's dense evergreen tropical forest vegetation, with an average temperature of $23{ }^{\circ} \mathrm{C}$ and annual rainfall between 1,500 and 3,000 m. Exploitation of forest resources (including NTFPs and hunting), agriculture (mostly cocoa production and poultry farming), and artisanal fishing remain the principal activities of most households. Increased temperatures and decreased rainfall results in nonavailability of NTFP, increase in animal species mortality, and decrease in crop yields. However, occasional drying up of swamps and marshlands provides an opportunity for vegetable cultivation, which is a beneficial effect of climate change (Sonwa et al. 2012; Bele et al. 2013; MINEPDED 2015).

\section{Farmers Household and Community Adaptation Strategies}

Cameroon has a National Adaptation Plan of Action (NAPA), which mentions gender issues in reference to the need to incorporate and prioritize women (as a homogenous group) in all sectoral adaptation initiatives at all levels in the different agro-ecological zones. Although the NAPA has clearly defined adaptation initiatives developed by state institutions at national level, its effective implementation at regional and local levels is often limited by structural (poor-coordination within and across ministries), financial, and technological (outdated research and climatological stations) constraints. Thus, farmers and rural households do not rely solely on state assistance for adaptation options. Over the years, they have developed various individual and collective strategies (both on-farm and off-farm) to cope with, and lessen the adverse effects of climate change based on their local knowledge, perception, experience, and interpretation of natural phenomena. Although there is a variability among the adaptation practices of male and female farmers, in general, smallholder farmers (both male and female) adopt a combination of on-farm agricultural practices among the following (Molua 2009, 2011; Tingem and Rivington 2009; Innocent et al. 2016; Beckline et al. 2017):

- Use of improved seed varieties (drought-tolerant and early maturing varieties)

- Seasonal alterations of farm size and/or location

- Adjusting sowing/planting time (early planting in mono-modal and bimodal forest zones, late planting in Sudano-Sahelian and Guinean-Savannah zones) and sequencing (plant spacing, row orientation, terracing)

- Mixed farming, crop rotation, and agroforestry

- Manual irrigation of crops using boreholes, watering cans, and hand buckets

- Installation of sprinkler irrigation systems 
- Adjusting level and timing of fertilizer and pesticide application

- Gardening on dried marshlands and swampy areas (in the bimodal forest zones)

- Implementing soil-water conservation techniques (minimum tillage, mulching, use of compost/manure)

- Decreasing herd size, increasing livestock diversity, and switching to heat- and drought-tolerant animal species

- Seasonal animal migration to river banks (transhumance)

- Increase collection and marketing of NTFPs for food and income, respectively

In addition to these agricultural practices, farmers are increasingly engaged in various off-farm income-generating activities to cushion farm income shocks such as petty trading and migration (to seek employment). Distress sale of household assets and reduction in nonfood expenditures are also observed as more detrimental coping mechanisms. Although these individual adaptive measures are successful, there is a limit to its overall contribution in a broader community resilience. Collective action is therefore needed to build community resilience against climatic shocks. Hence, the aforementioned individual adaptation strategies are complemented by other community actions which include: community rotational saving schemes ("tontines" or "njangis") with lending possibility, group collection and marketing of NTFP, cultivation of fodder crops for livestock, creation of community fodder banks, creation of community firebreaks (protecting against wild fires), family/community information sharing meetings, and community regulation of common-pool resources (land, water, and forest) (Molua 2011; Bele et al. 2013; Innocent et al. 2016).

The array of on-farm and off-farm adaptation strategies used by farmers in Cameroon vary across the agro-ecological zones and is influenced by an intersection of other factors such as gender, property rights, educational level, income (including credit access), access to technical assistance and extension services (including climate-related research and information) (Molua 2009; Innocent et al. 2016). This highlights the importance of intersectionality in climate change vulnerability and adaptation as will be discussed later.

\section{Women and Land Tenure in Cameroon}

Land governance/tenure in Cameroon is characterized by a plurality of normative orders, wherein the effective "rules-in-use" and daily management practices are determined by the interaction between colonial and post-independence state "law" (state normative order) on one hand, and the existing social/cultural norms of the people on the other hand (Belaunde et al. 2010; Pumenta 2014). A series of gender-neutral laws, decrees, ordinances, and their corresponding implementing institutions define the state normative order. Shaped by its colonial history, the state normative order, which is applicable to the entire national territory, is based on the notion of "private ownership" and land registration documented by formal instruments (title deeds) as a basis for securing property rights and economic development. Resource access and subsequent rights are therefore determined by the 
ability to pay (Van den Berg 1996; Fonjong 2012; Fonjong et al. 2013; Pumenta 2014; Njoh et al. 2017). This provides equal opportunity for all irrespective of gender, ethnicity, or religious background to have unchallenged rights over land. However, various financial and socio-cultural factors shape the gender-differentiated access to land.

The religious and social/cultural norms (non-state normative order) governing land are based on communal ownership, with slight differences across the country especially concerning women's land claims, as these engulf gender norms and roles embedded within unequal and changing power relations (Faith 2019). Cameroon is made of over 250 different ethnic groups spread across the ten regions of the country with diverse gender ideologies, norms and roles in relation to land, natural resource management, and agricultural production (Njoh et al. 2017; Faith 2019). Thus, as Van den Berg (1996) opines, "ideas about breadwinnership, the division of labour and responsibilities within the household largely influence women's access to land" (p. 18). However, these 250 ethnic groups can be regrouped under three main communities based on their religious (Christian or Muslim), linguistic (Arabic, French, or English), and colonial history, namely (Van den Berg 1996; Ahidjo 2012; Njoh et al. 2017; Faith 2019):

- Muslim community: made of the French- and Arabic-speaking Adamawa, North and Far North Regions of Cameroon, colonized by the Arabs, Germans, and French.

- Anglophone community: predominantly Christians and comprised of the English-speaking North-West and South-West Regions of Cameroon, colonized by the Germans and British.

- Francophone communities: predominantly Christians and comprised of the French-speaking South, East, West, Littoral, and Center Regions of Cameroon, colonized by the Germans and French.

Within these communities, a woman's access to and rights over land is determined by a mix of colonial, state, and non-state normative orders, influenced by other social determinants such as gender norms, ethnicity, and socio-economic status. The following sections highlights daily struggles female farmers encounter to access arable land across the different communities.

\section{Muslim Communities}

Within the Muslim communities, an important determinant of a female farmers' intra-household access to land is her marital status, as wives primarily rely on their husbands to gain access to farmland. However, access to farmland is not automatic upon marriage but earned through years of marital compliance, successful reproduction, and labor provision on the family field/farm. Wives are granted permissive use rights on degraded marginal or fallow lands for food crop cultivation, while their husbands still hold control and transfer rights over the land. With divorce or 
widowhood, divorcees lose access and rights over family land while widows with minor children may be granted usufruct and "limited" control rights over land held in trust of their son (the heir to the land). Nevertheless, wives, divorcees, and widows have devised alternative means to temporarily obtain farmland in their community within the appropriate socio-cultural norms used to enforce their land claims, such as renting and sharecropping. Inheritance and purchasing land could be a viable option of obtaining secured property rights but land ownership by "women" is stereotyped as a threat to family unity (decrease of sibling/son's inheritance or signs of marital discord), thus land purchase by women is almost inexistent within the Muslim communities. Furthermore, daughters and widows can only inherit land in the complete absence of a male relation (which is never the case) (Van den Berg 1996; Ahidjo 2012; Faith 2019). The insecure and temporary nature of these land tenure arrangements often limits the amount of investment Muslim women can and are willing to make on the farmland. With the advent of climate change, their adaptation strategies are therefore constrained.

\section{Anglophone Communities}

Within the household, Anglophone women also acquire land through male relations (fathers, husbands, and sons). However, differences exist in the rights and degree of control Anglophone women hold over land. Daughters are granted "permanent" use rights on family land and could inherit the land provided she remains unmarried even though sons are prioritized in relation to land inheritance. Upon marriage, wives are automatically granted usufruct rights on family land by her husband or his kinsmen, to ensure their principal duty of household food production (unlike Muslim wives who earn their access to farmland). At the discretion of the kinsmen, widows may keep their farmland as trustees for their sons (patrilineal inheritance) or nephews (matrilineal inheritance) with a greater degree for control and management rights. Divorced women are dispossessed of any rights they held over the husband's family land and return to their natal family for land or seek alternative strategies of acquiring farmland. However, although men in this community "own" the land, women hold the decision-making power and controls what is cultivated on the land, how her labor is allocated, and how the farm proceeds are used (Van den Berg 1996; Pumenta 2017; Faith 2019).

Besides relying almost exclusively on male relations for farmland, in the community sphere, Anglophone women (daughters, wives, mothers, widows, or divorcees) have also been known to "clear and claim" land as their own, as well as acquire land through renting, collective access of communal land, purchase, and registration. Irrespective of any socio-cultural and administrative bottlenecks (gender-biased norms, high cost, bureaucracy, etc.) associated with women's land purchase, Anglophone women have been able to circumvent these obstacles by using male relatives to buy land or "courting" both traditional and state authorities to buy land in their name (Van den Berg 1996; Pemunta 2017; Faith 2019). Although possible variability in terms of income levels, class, educational level, and social 
relations influence their land claims and rights enforcement, women (state bureaucrats, elites, and "business" women) own about $3 \%$ of the registered land in the Anglophone communities (Pemunta 2017). Furthermore, regrouping themselves into farmers organizations to access communal land and also pool resources to purchase land for collective food production and market gardening is an important strategy for which Anglophone women have proven to exert more power in bargaining and enforcing their land claims within both state and non-state normative orders (Fonjong et al. 2013; Pumenta 2017; Faith 2019). Although, variations exist in terms of access to land and security of tenure, most Anglophone women have more or less "secured" property rights and can therefore make pertinent management decisions to undertake long-term sustainable investments on their farmlands and reap the benefits. They are therefore more likely to adopt sustainable climate smart practices to cope with the adverse effects of climate change.

\section{Francophone Communities}

A Francophone woman's primary duty within the household (in accordance with socio-cultural norms) is to provide labor support on the family farm. Hence, access to land is conditioned on her "relationship" with the men in the family. Daughters assist in farming activities as well as the collection and processing of NTFPs. Upon marriage, wives acquire a share in the land of her mother-in-law or husband, on which they can cultivate food crops and vegetables (Fonjong 2012; UICN-PC 2015). Although men hold superior power over women (daughters and wives), household decisions over crop production and labor allocation are jointly made by husband and wife. Furthermore, the sociocultural norms generally protect the land claims of all farmers irrespective of gender, social identity, or ethnic origin (women can and do inherit land), although in some rare instances, widowhood and divorce may lead to loss of farmland by women (Gyau et al. 2014; UICN-PC 2015). Besides relying on family relations for land, women (wives and widows) also engage in temporary arrangements such as renting and sharecropping as alternative means of accessing additional farmland with limited management rights over these lands. Nevertheless, some financially viable women occasionally purchase land for construction or other non-agricultural developmental purposes in urban areas as evidenced in the Center Region where women (mostly state bureaucrats) own about $15 \%$ of all registered land (Gyau et al. 2014; Pumenta 2017). Thus, Francophone women generally have secured property rights that provides them with the power and means to equitably negotiate the diversification of their livelihoods and adapt to climatic changes.

In summary, despite the diverse socio-cultural norms across the country, the land rights of most Cameroonian women are co-dependent on male relations. However, the effective rule-in-use over land management as well as the intra-household decision-making power varies across these communities. Nevertheless, women contribute substantially in agricultural production and other livelihood activities, and are primarily responsible for household subsistence despite the genderdifferentiated access and rights to resources. 


\section{Intersectionality and Climate Change Adaptation}

Beyond the binary division of men versus women, a combination of other societal norms and socio-economic factors influence women's adaptive capacity. Consequently, an intersectional analysis is required to understand the underlying norms, power relations, and socio-economic factors that conditions the daily/seasonal adaptation practices, and strategies employed by women (Kaijser and Kronsell 2013; Carr and Thompson 2014). In Cameroon, with over 50\% of the female population relying on agriculture and natural resources for sustenance (Molua 2011; Pumenta 2017), women constitute an important group for whom risk aversion is vital for household welfare. However, the degree of vulnerability and effects of climate change on the livelihood activities of women depends on their location (agro-ecological zone), the diverse socio-cultural norms that prescribe access to and control over land, and decision-making power (as presented in the previous sections). Consequently, the adaptation strategies of women will vary across the country based on an intersection of gender, ethnicity, and agro-ecological location, as well as other factors such as educational level, access to information, access to extension services (technical assistance), income (including access to credit), social capital, etc. Hence, based on the findings of the previous sections, this section analyses the effects of an intersection of gender, ethnicity (in terms of land governance and decision-making power), and agro-ecological location (and other factors) on women's adaptation options within the northern Muslim community, southern Francophone and Anglophone communities. Figure 2 highlights the spatial distribution of these communities across the different agro-ecological zones.

\section{Women and Climate Change Adaptation Within the Muslim Community}

The Muslim community of Cameroon is predominantly located in the northern semiarid agro-ecological zones, comprised of the Sudano-Sahelian and Guinean Savannah agro-ecological zones. Climatic variations and extreme weather events such as droughts, heat weaves, dry spells, and occasional floods lead to decreased crop yields/productivity and increased population migration to other regions (mostly men) (Yengoh et al. 2010; Pumenta 2014; MINEPDED 2015). In line with their domestic/reproductive roles, Muslim women are generally involved in food crop production (on marginal lands acquired through male relations), processing and marketing of livestock and fishery products but lack control over how the proceeds are used (Van den Berg 1996; Ahidjo 2012; Njoh et al. 2017).

The temporary migration of Muslim men during periods of transhumance and in search of off-farm employment in other regions implies an increase in the number of de facto female-headed households with increases in the reproductive and productive activities of wives who are left to care for ("sick") family members while ensuring sufficient food production for the household. Although some women are engaged in petty trading, the increased workload of domestic activities limits their possibility of 


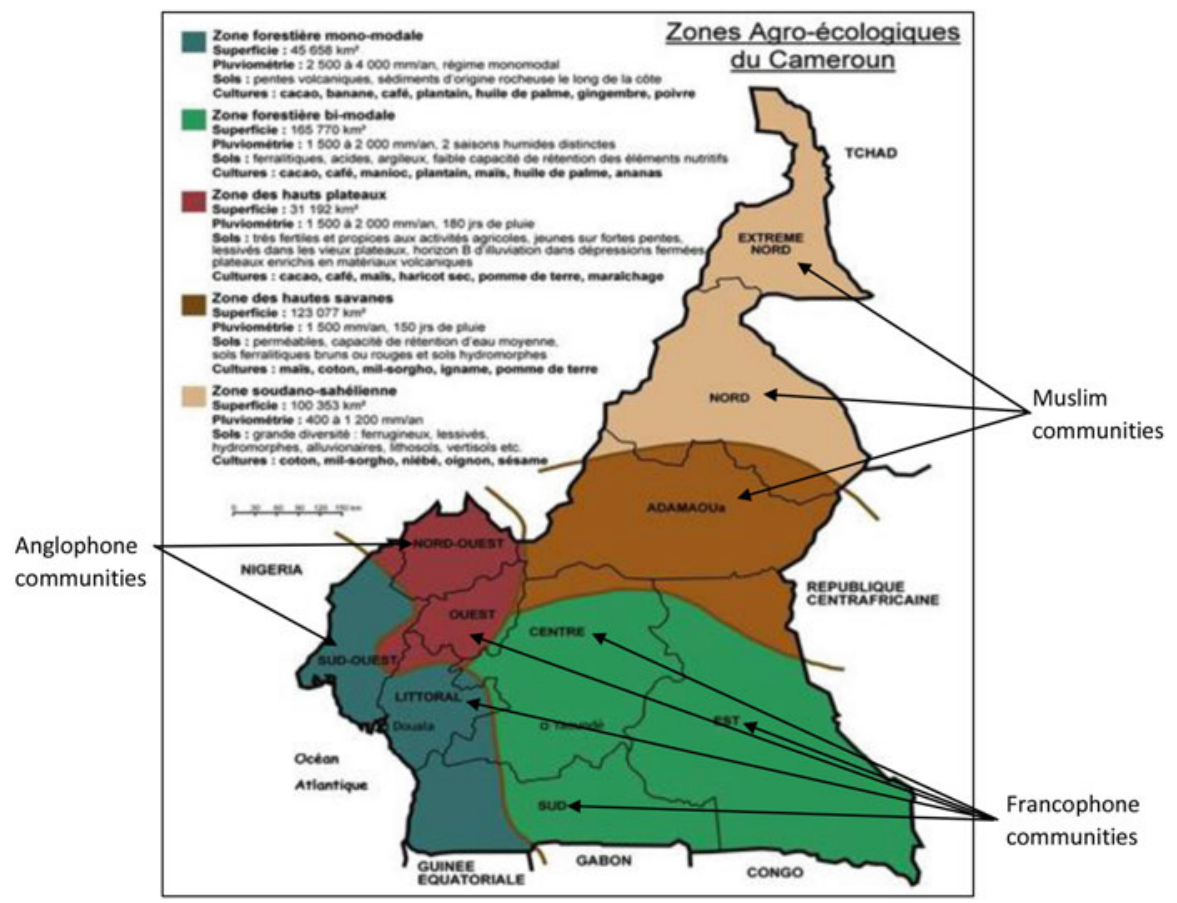

Fig. 2 Spatial distribution of the various communities across the different agro-ecological zones. (Source: Adapted from MINEPDED 2015)

diversifying their livelihood strategies and undertaking off-farm activities that could contribute to the household income. This is further exacerbated by the high illiteracy level among Muslim women, due to the gender ideology that prioritizes early marriage over girls' continuous education, thereby limiting their options of offfarm employment (Van den Berg 1996; Pumenta 2014). Furthermore, men generally hold decision-making power over the wife's labor and income allocation. Thus, for most Muslim women (wives, widows, mothers, and divorcees), their livelihood activities and adaptation strategies are centered around on-farm activities.

The on-farm adaptation strategies of Muslim women are constrained by religious and sociocultural norms that "forbid" ownership of land by women. Since women (daughters, wives, widows, and divorcees) only have usufruct rights on family or rented/sharecropping land, and "limited" decision-making power, their on-farm adaptations strategies are therefore limited to seasonal crop management practices and farming operations such as alterations in planting dates, use of drought tolerant or early maturing hybrid seeds, and mixed cropping. Furthermore, because of the limited property rights and temporal tenure arrangements (renting or sharecropping), Muslim women are unlikely to cultivate cash crops (except millet) that could increase their income (Van den Berg 1996; Molua 2011, 2012). The exception seems to be the case of widows with minor sons who have "limited" control rights 
over land held in trust for their sons. These widows can therefore undertake longterm investments such as tree planting (agroforestry) and soil management to safeguard the land while ensuring continuous household food production. As Van den Berg (1996) highlights, tree planting was used by widows as a means of securing and enforcing their land claims.

Beyond security of tenure and decision-making power, the choice of on-farm adaptation strategies implemented varies among women and is influenced by other factors such as income (to purchase drought tolerant or early maturing hybrid seeds), access to climate information and technical assistance. While farmers may generally have knowledge of the weather forecast and expected start of farming seasons (Molua 2011, 2012), Muslim women generally have limited access to agricultural extension services, as these services often target cash crop producers who are predominantly men. This limits the effective implementation of State's adaptation initiatives as stipulated in the country's NAPA, by sidelining the female population of farmers. Furthermore, while promoting tree planting in semi-arid zones is an essential adaptation initiative of the State (MINEPDED 2015), the limited property rights of Muslim women is a disincentive to engage in tree planting as they may not reap the benefits agroforestry provides in the long run. Thus, a gap exists between the national institutional framework and realities on the ground. Together, the aforementioned factors coupled with the limited livelihood diversification strategy of women and socio-cultural constraints on their adaptive capacity tend to increase the household and community vulnerability, thereby accentuating poverty in the regions.

\section{Women and Climate Change Adaptation Within the Anglophone Community}

The Anglophone community is comprised of the North-West and South-West Regions of Cameroon spread in two different agro-ecological zones. The NorthWest Region (NWR) is located within the western highlands zone, while the South-West Region (SWR) is located within the mono-modal forest zone. Climatic variations in the NWR leads to soil degradation (through leaching and erosion) and consequently drop in crop yields. In the SWR, extreme weather events, such as floods, lead to increased proliferation of malaria parasites, high incidence of waterborne diseases, saline water intrusion and destruction of salt-intolerant crops (MINEPDED 2015; Innocent et al. 2016; Beckline et al. 2017). In line with their reproductive roles, ensuring household food security is the responsibility of Anglophone women. Thus, farming (food crop and vegetable production) is the main livelihood activity of most women in these communities (Van den Berg 1996; Fonjong et al. 2013).

Health issues resulting from malaria parasites or waterborne diseases implies an increased workload on the domestic/reproductive roles of women (wives, mothers, widows, and divorcees) to nurture and care for the sick family members. This also increases their workloads in agriculture since they are tasked with ensuring 
household food security. However, Anglophone women as wives, widows, and divorcees decide and control how their labor or any proceeds from their farms is allocated (Van den Berg 1996; Pumenta 2017). They therefore have the possibility of diversifying their livelihood strategies and engaging in other flexible off-farm activities to generate income that could caution the adverse effects of climate change on their agrarian livelihood base. This is further facilitated by their relatively high literacy level (compared to the Muslim women) that enables them gain off-farm employment. From the researcher's lived experience, the high literacy level within Anglophone women may be considered the result of a trade-off wherein the education of female children serves as compensation for their limited inheritance rights.

Although an interaction of sociocultural norms and state "laws" dictate women's access to land and other natural resources, some Anglophone women have been able to manoeuver and "forum shop" from both systems to acquire more or less "secured" property rights over their farmland. While "high" income women such as state bureaucrats, elites, and "business" women have been able to purchase, title, and effectively own land, rural women with limited financial capital rely on their social networks/capital to regroup themselves and gain "secured" access to community land. Furthermore, by virtue of being the "breadbaskets" of the family, women generally have secured access to "family" land whether as a daughter, wife, mother, or widow (Fonjong et al. 2013; Pumenta 2017). Thus, the security of tenure provides an incentive to adopt and invest in sustainable soil management and agricultural practices such as agroforestry, recycling of dead organic matter, mulching, and reap the long-term benefits. Nevertheless, Anglophone women also engage in seasonal farming practices such as making "mounds," mixed cropping, off-season replanting, use of improved seed varieties, changing planting dates, etc. as coping strategies to the fluctuating climates in these zones (Beckline et al. 2017).

Beyond security of tenure and decision-making power, access to climate information and agricultural extension services also influence the on-farm adaptation strategies implemented by Anglophone women. Although both women and men get access to climate information from formal (weather observatory officers) sources through radios, print media, and televisions, as well as informal sources such as friends, family, and self-help groups (Molua 2011; Fonjong et al. 2013), access to agricultural extension services is correlated to group membership, social status, and class. While extension services target farmers groups/cooperatives (irrespective of the gender composition of the groups), "working class" women have the possibility of networking with and obtaining assistance from extension agents. Thus, being a full-time "housewife" and belonging to no farming group impinges on a woman's access to technical assistance. However, most Anglophone women belong to selfhelp and community saving groups ("njangis") which serves as a buffer against financial crisis in times of disasters and emergencies on one hand, and as a platform of socialization, information sharing, and peer learning within the communities on the other hand (Molua 2011; Fonjong et al. 2013; Innocent et al. 2016). Thus, Anglophone women seem less vulnerable and more proactive in adopting conservation and protective on-farm practices compared to their Muslim counterparts. 


\section{Women and Climate Change Adaptation Within the Francophone Community}

The Francophone community is made of five administrative regions spread across three different agro-ecological zones. It is comprised of the West Region (located in the western highlands zone), the East, South, and Center Regions (located in the bimodal forest zone), and the Littoral Region (located in the mono-modal forest zone). Seasonal weather fluctuations in the western highlands and bimodal forest zones lead to soil erosion and drop in crop yields, and increased scarcity of NTFPs. In the mono-modal forest zone, sea level rise and extreme weather events, such as floods, leads to increased proliferation of malaria parasites, high incidence of waterborne diseases, saline water intrusion and destruction of salt-intolerant crops (Yengoh et al. 2010; Sonwa et al. 2012; Bele et al. 2013; MINEPDED 2015).

In addition to their reproductive roles, a Francophone woman's main duty as a daughter or wife is to provide labor support on the family farm. Although cash crop (mainly cocoa) production and fishing by men are the main livelihood activities, Francophone women (wives, mothers, divorcees, and widows) are involved in food crop and vegetable production on farmland acquired through diverse means. With both the state and non-state normative orders protecting the land and natural resource claims of women, the security of tenure provides women with the power to negotiate the diversification of their livelihoods. Being educated and earning an income is a bonus as it influences the intra-household bargaining power of women. Women therefore engage in diverse off-farm employment and income-generating activities such as petty trading of food crops, collection, processing and marketing of NTFPs, as well as processing and marketing of fishery products (Sonwa et al. 2012; Brown and Sonwa 2015; UICN-PC 2015; Beckline et al. 2017; Pumenta 2017). This offfarm income helps caution against the negative effects of changing climatic conditions on the agrarian livelihood base of the household. Furthermore, Francophone women engage in precautionary loan-savings schemes ("tontines") which provides women with easy and flexible access to credit that is used for on-farm and/or offfarm income-generating activities. This contributes in enhancing household income and general welfare, as well as provide financial insurance in times of disasters and emergencies. Francophone women also engage in community labor-sharing groups that provides mutual labor support on their farm. Since membership to these are based on trust, solidarity, and reciprocity, these groups are indicative of the social capital within this community, which can serve as an entry point for distribution of information, peer learning, and technology adoption (Molua 2011; Bele et al. 2013; Brown and Sonwa 2015), and thereby enhance their general well-being and adaptation potential.

Like the Anglophone and Muslim women, the incidence of malaria and waterborne diseases implies a disproportionate burden on the reproductive activities of women to nurture and care for the sick family members. However, since household farming decisions are jointly made (Gyau et al. 2014), wives have the possibility to trade-off their on-farm labor support with domestic care roles. 
In summary, although female farmers across Cameroon seem to opt for relatively low resource (cost and labor) on-farm adaptation methods which can contribute to yield stabilization (Molua 2011), a variability exist among these women influenced by a combination of other socio-cultural norms and socio-economic factors. This aligns with growing literature on gender, intersectionality, and climate change which has shown that socio-cultural norms including gender relations and power dynamics which determines resource allocation and use, division of labor, and decisionmaking within and beyond the household influence the adaptation strategies of women. Furthermore, an intersection of other socio-economic factors jointly determines the adaptation options and choices available to women. These factors include income/wealth, educational level, place/location, marital status, class, ethnicity, group membership, access to information, technology, extension services, etc. Nevertheless, irrespective of any constraint posed by societal/sociocultural norms and other socioeconomic factors, female farmers continue to exercise their agency and adapt to changing climatic conditions in diverse ways as the circumstances present. Thus, the adaptation strategies of women within agrarian societies in Cameroon are context specific.

\section{Caveats/Limitations of the Study}

This desk study adopts a critical theorist (feminist) stance, which guides the scope of analysis and recommendations with an undeniable bias of the researcher's position. This chapter is led by a female agronomist, with lived experiences of the daily struggles Cameroonian women encounter over land and natural resources. Although the authors aim to limit the researcher's influence through self-reflective honesty and interaction with the second, more distant author, it cannot entirely erase the influence of this specific positionality, but this should not be considered a problem in this exploratory study. Furthermore, because this study relies exclusively on secondary literature (with minimal sex disaggregated data), its analysis is not exhaustive of the current realities, dynamics, and complexities of climate variability/change on agrarian livelihood systems on the ground, an in-depth field research will be needed to achieve this. Nevertheless, the conclusion and modest recommendations will shed light on the ongoing debate on intersectionality and climate change adaptation, and propose alternatives that can work in Cameroon.

\section{Conclusion}

In line with the growing debate on gender, intersectionality, and climate change, this study set out to examine the adaptation strategies of women in Cameroon using an intersectional lens. As discussed, the vulnerabilities and effects of climate change differs across the five agro-ecological zones of Cameroon with the Sudano-Sahelian zone being the most vulnerable zone. While the National Adaptation Plan of Action (NAPA) provides an institutional framework for agrarian adaptation strategies, 
limited coordination among sectorial ministries impedes the effective implementation of these strategies at regional and local levels. Furthermore, by classifying women as a monolithic group, the NAPA ignores the various institutional arrangements (gender norms, resource ownership, property rights etc.) and socio-economic factors (education, income, marital status, etc.) that determines the vulnerabilities and adaptation strategies of women. Thus, the national adaptation initiatives targeting women are poorly designed and seems destined to fail from its conception. Nevertheless, farmers (women inclusive) have a wide range of on-farm agricultural practices and off-farm adaptation strategies that are used to counteract the adverse effects of climate change while enhancing their livelihoods and well-being.

With land being a crucial production factor within agrarian communities, resource ownership and property rights constitute an important determinant in the adaptation choices and options of farmers especially women. However, the analysis shows that land tenure/governance across the national territory is diverse and embedded within a complex web of gendered identities, norms, roles, ethnicity, and power dynamics, for which women have to negotiate resource access with other actors. The outcome of these negotiations translates differently for women across the Muslim, Anglophone, and Francophone communities of Cameroon, and therefore influences the on-farm adaptation options and choices of female farmers in these communities.

Beyond gender and security of tenure, we have shown in this study that a range of other factors influences the adaptation strategies of female farmers across the different agroecological zones of Cameroon. These factors include decision-making power, income/wealth, level of education, access to information, access to technical assistance, group membership, and social identity/status (daughter, wife, mother, widow, or divorcee). A variability therefore exists in both the on-farm and off-farm adaptation choices and options available and adopted by women within and between communities be it in the northern semi-arid agro-ecological zone or the Southern savannah and forest agro-ecological zones. Hence, the adaptation strategies of female farmers in Cameroon is highly context specific. These findings are not unique to Cameroon, as research elsewhere have shown the intersection of socio-economic factors on climate change adaptation across Africa (see Boltana (2017) for group membership in Southern Ethiopia, Elum et al. (2017) for access to information in South Africa, Van Aelst and Holvoet (2016) for marital status and intra-household decision-making in Tanzania, etc.). Nevertheless, the study contributes to the current global debate on gender, intersectionality, and climate change by providing insights from the Cameroonian context.

\section{Recommendations}

Despite the limited sex-disaggregated and quantitative data, this study could serve as an "eye-opener" and a foundation for further research on intersectionality and climate change adaptation in Cameroon. Thus, an in-depth and contextually grounded analytical research is recommended to shed more light on the existing 
variabilities among female farmers within and between the different communities and agroecological zones. Nevertheless, based on this study, a few modest policy recommendations can be proposed as a way forward in enhancing the adaptation strategies of female farmers in Cameroon.

First, ensuring secured access to land for women especially within the Muslim communities can create a window of opportunity to strengthen their bargaining power and enhance their adaptation strategies. While the national land tenure reform proposed in the NAPA seems apparent as a solution, there is need to incorporate "Muslim doctrines" and make special legal provisions for Muslim women who seem to be the most disadvantaged in relations to property rights compared to their Anglophone and Francophone counterparts. Bearing in mind that security of tenure goes beyond state recognition to a matter of power struggles and social relations, sensitizing women on their "constitutional rights to property" and putting in place (or revamp existing) accompanying institutions to ensure effective implementation and gender justice will go a long way to improve the agrarian livelihood and adaptation strategies of female farmers. Also, promoting female farmer groups, cross-country exchanges and engaging with ideological debates about gender and land rights is a step in the right direction towards secured property rights for women.

Second, as education and income have shown to enhance the bargaining power and off-farm adaptation options of women within the Anglophone and Francophone communities, improving the literacy levels and socioeconomic capacity of Muslim girls and women is necessary. Beyond improved literacy levels and socio-economic capacity, education can serve as an empowerment strategy geared towards creating pathways of transforming gender norms in the long run. Thus, affirmative action through educational and vocational training scholarships could be a policy measure of the Ministry of Women Empowerment and the Family (MINPROFF) to improve overall livelihood and adaptation strategies within Muslim communities. Nevertheless, girls from rural areas, especially of enclaved areas within the Anglophone and Francophone communities, should be considered too.

Third, access to information and technical assistance has shown to be significant factors determining the on-farm agricultural adaptation practices of women. Thus, governmental effort by the Ministry of Scientific Research and Innovation (MINRESI) and Ministry of Agriculture and Rural Development (MINADER) in revamping existing meteorological services and making information and extension services more readily and widely available is crucial to enhance the adaptation decisions that women make. While priority should be given to the northern semiarid zones with frequent droughts and floods as well as the coastal lowlands with frequent floods, storm surges, and mass movements, the other agro-ecological zones should not be neglected as the impacts of climate change in one agroecological zone inherently affects the populations in the other zones.

Fourth and last, community groups (farmer's cooperatives, self-help, "tontines," and "njangis") seem to be a viable option for peer learning, information sharing, financial assistance, and mutual support in Anglophone and Francophone communities. These groups could also serve as a transformative tool to mobilize the power of collective action in strengthening the bargaining power of women within the communities, as illustrated by Anglophone women groups in relation to access to land. The 
potential of these groups should be explored and supported to collectively build the adaptive capacity of women and community resilience, through initiating and training members on income-generating entrepreneurial activities, and linking these groups to microfinance institutions/banks for financial assistance through credit. Also initiating such groups within the Muslim community (if none currently exist) could be beneficial too in reducing their vulnerability and enhancing that adaptive capacity. Both MINADER and MINPROFF could spearhead such initiatives.

\section{References}

Ahidjo P (2012) Access to land and the system of land ownership in Northern Cameroon. J Knowl Manag Econ Inf Technol 2(3):1-11

Arora-Jonsson S (2011) Virtue and vulnerability: discourses on women, gender and climate change. Glob Environ Chang 21(2):744-751. https://doi.org/10.1016/j.gloenvcha.2011.01.005

Beckline M, Yujun S, Ayonghe S, Etta OL, Constantine I, Richard T (2017) Adaptation of women to climate variability in the southern slopes of the Rumpi Hills of Cameroon. Agric For Fish 5 (6):272-279. https://doi.org/10.11648/j.aff.20160506.19

Belaunde S, Cortes M, Hogstad J, Ku E, Nascimento K, Trzcinski L (2010) Land, legitimacy and governance in Cameroon. Institute for Research and Debate on Governance and Columbia University School of International and Public Affairs. 70p. Retrieved from: http://www.institutgouvernance.org/IMG/pdf/sipa_cameroon_land_legitimacy_governance-2010.pdf

Bele MY, Tiani AM, Somorin OA, Sonwa DJ (2013) Exploring vulnerability and adaptation to climate change of communities in the forest zone of Cameroon. Clim Chang 119:875-889. https://doi.org/10.1007/s10584-013-0738-z

Boltana TF (2017) The role of women Self Help Group membership towards collective action in women's adaptive capacity building under changing climatic situations in rural Ethiopia; a case study in Kindo Koysha District; Southern Ethiopia. Masters dissertation, Institute of Development Policy, University of Antwerp, Belgium

Brown HCP, Sonwa DJ (2015) Rural local institutions and climate change adaptation in forest communities in Cameroon. Ecol Soc 20(2):6. https://doi.org/10.5751/ES-07327-200206

Carr ER, Thompson MC (2014) Gender and climate change adaptation in agrarian settings. United States Agency for International Development, Washington, DC

Cho S, Crenshaw KW, McCall L (2013) Toward a field of intersectionality studies: theory, applications, and praxis. J Women Cult Soc 38(4):785-810

Davis K (2008) Intersectionality as buzzword: a sociology of science perspective on what makes a feminist theory useful. Fem Theory 9(1):67-85. https://doi.org/10.1177/1464700108086364

Denton F (2002) Climate change vulnerability, impacts, and adaptation: why does gender matter? Gend Dev 10:10-20. https://doi.org/10.1080/13552070215903

Elum ZA, Modise DM, Marr A (2017) Farmer's perception of climate change and responsive strategies in three selected provinces of South Africa. Climate Risk Management16:246-257. https://doi.org/10.1016/j.crm.2016.11.001

Faith AN (2019) Whose land is it? Women's struggles over land in Cameroon (End-of-ModulePaper). IOB, University of Antwerp, Antwerp

Fonjong LN (2012) Equal rights but unequal power over land: rethinking the process of engendering land ownership and management in Cameroon. In: Fonjong LN (ed) Issues in women's land rights in Cameroon. Langaa RPCIG, Mankon Bamenda, pp 19-41

Fonjong L, Fombe L, Sama-Lang I (2013) The paradox of gender discrimination in land ownership and women's contribution to poverty reduction in Anglophone. GeoJournal, 78(3), 575-589. https://doi.org/10.1007/s10708-012-9452-z

Gyau A, Faith AN, Fondjem-Tita D, Ajaga N, Catacutan D (2014) Small-holder farmers' access and rights to land: the case of Njombé in the littoral region of Cameroon. Afrika Focus, Special Agroforestry Issue 27(3):23-39 
Hankivsky O (2014) Intersectionality 101. Institute for Intersectionality Research and Policy, Simon Fraser University, Vancouver

Innocent NM, Bitondo D, Azibo BR (2016) Climate variability and change in the Bamenda highlands of North Western Cameroon: perceptions, impacts and coping mechanisms. Br J Appl Sci Technol 12(5):1-18. https://doi.org/10.9734/BJAST/2016/21818

Kaijser A, Kronsell A (2013) Climate change through the lens of intersectionality. Environ Polit 0 (0):1-17. https://doi.org/10.1080/09644016.2013.835203

Kings AE (2017) Intersectionality and the changing face of ecofeminism. Ethics Environ 22 (1):63-87. https://doi.org/10.2979/ethicsenviro.22.1.04

MINEPDED - Ministère de l'Environnement, de la Protection de la Nature et du Développement Durable (2015) Plan National d'Adaptation aux Changements Climatiques du Cameroun. Yaoundé, Cameroon: 138 pages + Annexes

Molua EL (2009) Accommodation of climate change in coastal areas of Cameroon: selection of household-level protection options. Mitig Adapt Strateg Glob Chang 14:721-735. https://doi. org/10.1007/s11027-009-9194-5

Molua EL (2011) Farm income, gender differentials and climate risk in Cameroon: typology of male and female adaptation options across agroecologies. Sustain Sci 6:21-35. https://doi.org/ $10.1007 / \mathrm{s} 11625-010-0123-\mathrm{z}$

Molua EL (2012) Gendered response and risk-coping capacity to climate variability for sustained food security in Northern Cameroon. Int J Clim Change Strat Manag 4(3):277-307. https://doi. org/10.1108/17568691211248739

Ngondjeb YD (2013) Agriculture and climate change in Cameroon: an assessment of impacts and adaptation options. Afr J Sci Technol Innov Dev 5(1):85-94. https://doi.org/10.1080/20421338. 2013.782151

Njoh AJ, Ananga EO, Anchang JY, Ayuk-Etang EMN, Akiwumi FA (2017) Africa's triple heritage, land commodification and women's access to land: lessons from Cameroon, Kenya and Sierra Leone. J Asian Afr Stud 52(6):760-779. https://doi.org/10.1177/0021909615612121

Osborne N (2013) Intersectionality and kyriarchy: a framework for approaching power and social justice in planning and climate change adaptation. Plan Theory XX(X):1-22. https://doi.org/10. $1177 / 1473095213516443$

Pumenta NV (2014) The impact of climate change on food security and health in Northern Cameroon. In: Keyes CB, Lucero OC (eds) New developments in global warming research; climate change and its causes, effects and prediction. Nova Science Publishers, New York, pp 1-55

Pumenta NV (2017) When 'property cannot own property': women's lack of property rights in Cameroon. Afr J Econ Sust Dev 6(1):67-85

Sonwa DJ, Somorin OA, Jum C, Bele MY, Nkem JN (2012) Vulnerability, forest-related sectors and climate change adaptation: the case of Cameroon. Forest Policy Econ 23:1-9. https://doi.org/10. 1016/j.forpol.2012.06.009

Tingem M, Rivington M (2009) Adaptation for crop agriculture to climate change in Cameroon: turning on the heat. Mitig Adapt Strateg Glob Chang 14:153-168. https://doi.org/10.1007/ s11027-008-9156-3

UICN-PC (2015) Stratégie de Prise en Compte des Femmes dans le Processus REDD+ au Cameroun. UICN (Union internationale pour la conservation de la nature et de ses ressources), Yaoundé, Cameroun: 73 pages + Annexes

Van Aelst K, Holvoet N (2016) Intersections of gender and marital status in accessing climate change adaptation: evidence from rural Tanzania. World Dev 79:40-50. https://doi.org/10.1016/ j.worlddev.2015.11.003

Van den Berg A (1996) Land right, marriage left: women's management of insecurity in North Cameroon. Research School CNWS, Leiden University, Leiden

Yengoh GT, Tchuinte A, Armah FA, Odoi JO (2010) Impact of prolonged rainy seasons on food crop production in Cameroon. Mitig Adapt Strateg Glob Chang 15:825-841. https://doi.org/10. 1007/s11027-010-9241-2 
Open Access This chapter is licensed under the terms of the Creative Commons Attribution 4.0 International License (http://creativecommons.org/licenses/by/4.0/), which permits use, sharing, adaptation, distribution and reproduction in any medium or format, as long as you give appropriate credit to the original author(s) and the source, provide a link to the Creative Commons license and indicate if changes were made.

The images or other third party material in this chapter are included in the chapter's Creative Commons license, unless indicated otherwise in a credit line to the material. If material is not included in the chapter's Creative Commons license and your intended use is not permitted by statutory regulation or exceeds the permitted use, you will need to obtain permission directly from the copyright holder.

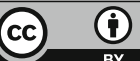

